\title{
Organizational Justice as a Predictor of Self-Perveived Work Performance: A Perspective from the Malaysian Higher Educational Institution
}

\author{
Arman Hadi Abdul Manaf \\ Open University Malaysia \\ Email: arman_hadi@oum.edu.my \\ Latifah Abdul Latif \\ Universiti Sains Malaysia \\ Juhary Ali \\ Asia e University
}

\section{Doi:10.5901/mjss.2014.v5n23p319}

\begin{abstract}
This study intends to examine the relationships between organizational justice and self-perceived performance in the Malaysian perspective. A higher educational institution in the Northern region of Malaysia was selected for this current study and the respondents are among expatriate academicians of various faculties. The sample of the study consisted of a total of 140 participants of various faculties. The hypotheses have been constructed and an investigation was undertaken to justify whether the independent variables selected are able to determine the self-perceived performance variable. The correlational and regressional analyses are to be utilized in attempt to examine causative effect of the data tested. As a result, the measurement of selected instruments was found to be a valid and reliable tool in this specific study.
\end{abstract}

Keywords: Organization justice; self-perceived performance

\section{Introduction}

Today, private and public sectors are highly competitive regardless of the nature of business and this situation permits the organizations to deal with tough decisions in a more even manner. Various organizations stressed on the quid pro quo exchange of monetary payment for the performance upon concrete tasks (Barley and Kunda, 1992 in Cropanzano, Bowen and Gilliland, 2007, pg. 34). The tasks are much often been formally appraised by the employees' superiors. In the case of public sector organizations, including public Higher Educational Institution (HEl), employees' motivation and performance level in the workplace is not only limited to the merit pay or benefits but they are related to the perceptions by the employees on the procedures, interactions and outcomes to be fair within their workplace, i.e. organizational justice.

According to Goudarzvandchegini, Aghajannashtaei and Shabaninashtaee (2012), past studies have identified that the element of justice has a significant function in organizations and influence on treatment toward beliefs, feelings, attitudes and behaviour of the employees. The behavioural role of employees are crucial in order to ensure the survival of the organizations they are serving, thus the major concerns for Malaysian organizations is the need to formulate a strategy for improving performance (Abdul, 2012).

In relations to this, an increasing concern on organizational justice and its effect on organizational outcomes such as performance outcomes (Elamin and Alomain, 2011) and in depth understanding on organizational justice and human behaviours (Hartman, Yrle and Galle, 1999) are vital. On the other hand, injustice dissolve bonding within the organization community and it is hurtful to individual and harmful to organizations. The more individuals are concerned about the organization, the more distressed they become when been treated unfairly.

Organizational justice refers to the organizational members' specific awareness of the moral appropriateness on means they are treated of which allowing them to work effectively. It is an area of which employees discern procedures in their working environment, reciprocal action and results of being fair (Baldwin, 2006). Justice states the intrinsic 
relationship between individual and employers. Justice furnishes an exceptional business opportunity, from gathering specific benefits such as stronger employee work commitment to acquiring a comprehensive competitive that dwells in a culture of justice.

However, in order to elevate performance among employees, the managers have to ensure that their employees are treated with dignity, fairly, respectfully, unbiased and show sensitivity towards them. Individual work performance is an issue that has seized corporations all over the world, but also has generated numbers of research in fields of management, occupational health and work and organizational psychology (Waldman, 1994; Campbell in Dunnette and Hough, 1990).

Vast amount of research in organizational justice have been conducted in Western countries, however small focus has been undertaken in assessing employee perceptions of fairness in Malaysia being no exception. According to Leung and Stephan (2001), examining cross-cultural research in the area of organizational justice is worthy by going beyond the boundaries of Euro-American in developing more constructive theories. This current study has the intention to investigate the relationships between organizational justice and self-perceived performance in the higher educational institution (HEI) in Malaysia.

\section{Literature Review}

Robbins (2005) defined justice as ethical decision criteria and it imposes and enforces rules fairly and impartially in order to have an equitable distribution of benefits and costs. Organizational justice anticipates employees' perception of fairness in the workplace. Fairness perceptions have received much attention due to its relations on individual and organizational outcomes.

Organizational justice describes the perceptions by individuals on fair treatment acquired from the employer as well as their behavioral responses towards it (Fernandes and Awamleh, 2006). Treating employees unfairly can adversely affect many different types of work attitudes and behaviours. Justice is the fundamental of each appropriate conduct.

Previous studies focussed on justice due to the important work-related outcomes that have been accociated to employees' perceptions of fairness within organizational contexts (Cohen-Charash and Spector, 2001; Colquitt, Conlon, Wesson, Porter and $\mathrm{Ng}, 2001)$. For instance, such outcomes of perceived fairness are job satisfaction and superior (Alexander and Ruderman, 1987 in Choudhry, Philip, Kumar, 2011), job commitment (Masterson, Lewis, Goldman and Taylor, 2000) and job performance (Ball, Trevino and Sims, 1994). A considerable interest has taken place to examine the antecedents of justice perceptions of promoting fairness in organizations.

Studies by Robinson (2004 in Manouchehri, Razavi and Emamgholizadeh, 2014); Erdogan and Liden (2006); and Cohen-Charash and Spector (2001) investigated the role of organizational justice on variables of organizational outcomes such as (i) job satisfaction, (ii) organizational commitment, (iii) motivational level, (iv) citizenships behaviour and (v) performance. The results concluded that three components of organizational justice were significant to all of these selected outcomes.

\subsection{Types of organizational justice}

Colquitt, Greenberg and Zapata-Phelan (2005); Ambrose and Arnaud (2005); Ball (2006); and Ambrose and Schminke (2003) stated that researchers from organizational behaviour identified three types of organizational justice namely; (i) distributive justice, (ii) procedural justice and (iii) interactional justice. It is an essential factor of successful organizations.

\subsubsection{Distributive justice}

Distributive justice refers to the perceived fairness of the results that an individual obtains from his or her employing organization. The referred results or outcomes may be distributed on the fundamental of equality, contribution and determination by individuals in the process of distribution of fairness compared to others (Alsalem and Alhaiani, 2007). According to Pourezat and Ghoulipour (2008), distributive justice indicates fair apportionment of benefits excavated from various activities in order for each organizational member to acquire fair portion based on the amount of inputs, cooperation and capabilities.

\subsubsection{Procedural justice}

Procedural justice is referred as the participants' perceptions on fairness of the rules and procedures of which regulated 
the process (Nabatchi, Bingham and Good, 2007; Nesbit, Nabatchi and Bingham, 2012). Robbins (2001) stated procedural justice means perceived justice of a process that is used to determine distribution of rewards. Procedural justice is an extent to which the dynamics of the decision process are judged to be fair (Dogan, 2008 in Memduhoglu and Yildiz, 2014). In other words, it refers to perceptions by individuals on fairness of present decision-making processes in order to reimburse their services instead of real distribution of incomes. Procedural justice is concerned on equality of procedures in decision-making. It refers to fairness in distribution of wages, participation during decision making as well information distribution within organization (Colquitt and Chertkoff, 2002).

\subsubsection{Interactional justice}

Poole (2007) stated that interactional justice is the quality of inter-individual behaviour whereby an individual is liabled before and after decision-making process. Interactional justice focuses on individual's perceptions on the features of interpersonal treatment obtained during the decree in decision making process as well as procedures which include various of individual behaviours upon social sensitivity such as respect, honesty, dignity, politeness displayed by originator of justice toward receipeint of justice (Bies, 2001; Cropanzano, Prehar and Chen, 2002). In other words, it refers ways individuals are treating each other. A person is interacting fairly if he or she delivers appropriate information and refraint inappropriate remarks (Cropanzano, Bowen and Gilliland, 2007). Interactive justice stresses on the quality of interpersonal relations among individuals. It is important for organizations to fairly consider on members' views during the decision making process, in order of respecting their rights and to enhance effective communication.

\subsubsection{Work performance}

Effective organizational functioning depends on various differing behavioural patterns. Job performance refers to the behaviours employees engage in while at work (Jex, 2002). It refers to how well someone performs at his or her work. Essentially, from an organizational member's point of view job performance refers to the outcomes of behaviours. Campbell, McHenry and Wise (1990) defined work performance as a behavioral state and Viswesvaran and Ones (2000) refer it as the measurable undertaken actions, behavior and results that are appropriate to the organizational goals.

\section{Methodology}

This study was based on the survey method in data collection process. A set of questionnaires were constructed and anchored by measurements utilized by past researchers. The organizational justice (Distributive, Procedural and Interactional) cited by Al-Zu'bi (2010) and self-perceived performance cited by Al-Dmour and Awamleh (2002) were adapted. The correlational and regressional analyses were computed by The Statistical Software of Social Sciences (SPSS) version 19.0 in examining the causal effect between variables selected.

\subsection{Research model and hypotheses}

The objective of this study is to develop a proposition in examining the essence of organization justice towards selfperceived performance. The framework of this study has been developed as shown in Figure 1.

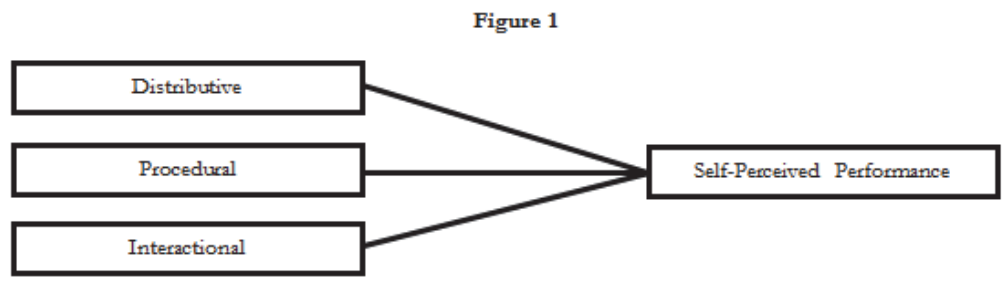

The hypotheses are as follows:

Ho1 Distributive justice has not significantly determines on self-perceived work performance.

Ha1Distributive justice has significantly determines on self-perceived work performance. 
Ho2Procedural justice has not significantly determines on self-perceived work performance.

Ha2Procedural justice has significantly determines on self-perceived work performance.

Ho3 Interactional justice has not significantly determines on self-perceived work performance.

Ha3 Interactional justice has significantly determines on self-perceived work performance.

\subsection{Sampling and data collection}

A survey questionnaire was applied as data collection instrument due to its ability to study a large sample randomly. A questionnaire is a printed self-report form designed to elicit information that can be obtained through the written responses of the subjects. The sampling of respondents of this study is the senior lecturers with a doctoral degree (PhD) as the unit of analysis of various faculties who are currently employed by a university in the Northern region of Malaysia. Sixteen faculties were contacted for agreement to participate in this study. Ten sets of questionnaires were submitted to each faculty (through the Faculty Dean) to be distributed to the faculty members (Expatriates). Out of the 160 questionnaires distributed, however only 140 were returned indicating 87.5 per cent response rate by the faculty members.

\subsection{Instruments for measurement}

A set of questionnaire on organizational justice (20 items) developed by Al-Zu'bi (2010) and Self-Perceived Performance (5 items) by Al-Dmour and Awamleh (2002) were tested in the pilot study. The measurement scales were anchored by a five-point Likert scale and the responses were based on (1 - Strongly disagree, 2- Disagree, 3 - Neutral, 4 - Agree and 5 - Strongly agree).

\section{Results}

The information gathered was based on the survey questionnaires which have been distributed to employees who are holding a technical position. The questionnaire used in this survey is based on the employees' perception on their work performance in the Faculty.

\subsection{Reliability analysis}

The faculty members were instructed to evaluate the perceptions on three dimensions of organizational justice namely; distribute, procedural and interactional. Total of 25 items were asked in the questionnaire. Therefore, to test the reliabilty of the instruments adapted, Cronbach Alpha (a) was apllied in order to measure the internal consistency of the chosen instrumentations of the constructs. The reliability test score for this study has been indicated as in Table 1. The value of 0.70 is the minimum acceptable standard score for Cronbach Aplha (Nunnally, 1978; Field, 2005).

\section{Table 1}

\begin{tabular}{lcc} 
Variables & Cronbach Aplha $(\boldsymbol{\alpha})$ & No. of Items $(\mathbf{N}=\mathbf{2 5})$ \\
\hline Distributive Justice (DJ) & 0.793 & 5 \\
Procedural Justice (PJ) & 0.812 & 6 \\
Interactional Justice (IJ) & 0.828 & 9 \\
Self-Perceived Performance (SPP) & 0.721 & 5
\end{tabular}

\subsection{Factor analysis}

The four (4) dimensions constituting of distributive justice, procedural justice, interactional justice and self-perceived work performance were measured. The suitability of data was assessed through factorial analysis. The correlational matrix has shown that the existence of many coefficients with the value of more than 0.5 and the items are remained. The KMO value for (i) distributive justice is 0.822 ; (ii) procedural justice is 0.736 , (iii) interactional justice is 0.773 and (iii) selfperceived performance is 0.738 . The results from the applied instrumentations in the study have satisfied the requirement of Kaiser-Meyer-Olkin (KMO) test. Validity is claimed when the value of variables are more than $0.05(p>0.05)$ as stated by Field (2005). 


\subsection{Correlation analysis}

The correlations are summarized in Table 2 as shown below.

\section{Table 2}

\begin{tabular}{|ccccc|}
\hline Variables & DJ & PJ & IJ & SPP \\
\hline DJ & 1 & & & \\
PJ & $0.421^{*}$ & 1 & 1 & 1 \\
IJ & $0.380^{*}$ & $0.354^{*}$ & $0.578^{\star *}$ & $0.633^{\star *}$ \\
SPP & $0.656^{\star *}$ & &
\end{tabular}

${ }^{*}$ Correlation is sig. at $p<0.05$

${ }^{*}$ Correlation is sig. at $p<0.01$

Correlation analysis was used to examine the relationship of the study's research framework as follows:

a) The relationship between Distributive Justice (DJ) and Self-Perceived Performance (SPP) has been identified whereby ( $r=0.656$ and $p<0.01$ : Ha1 is accepted, the Ho1 is rejected).

b) The relationship between Procedural Justice (PJ) and Self-Perceived Performance (SPP) has been identified whereby $(r=0.633$ and $p<0.01$ : Ha2 is accepted, the Ho2 is rejected).

c) The relationship between Interactional Justice (IJ) and Self-Perceived Performance (SPP) has been identified whereby ( $r=0.578$ and $p<0.01$ : Ha3 is accepted, the Ho3 is rejected).

\subsection{Regression analysis}

This section highlights on the data sets that have been regressed using enter method, in which all variables were entered in model 1 as shown in Table 3.

\section{Table 3}

\begin{tabular}{cccc} 
Variables & \multicolumn{1}{c}{ Model 1} & IJ \\
SPP & DJ & PJ & 0.501 \\
R-Square & 0.552 & 0.459 & 31.389 \\
F-value & 33.309 & 24.880 & 0.001 \\
Sig. & 0.003 & 0.000 &
\end{tabular}

As indicated in Table 3, it has been resulted that model 1 represents the three components of organizational justice on self-perceived performance. According to the estimated model:

a) The estimated R-square, only 55.2 per cent of changes in dependent variable (self-perceived performance) is possible to be accounted for by distributive justice; followed by 45.9 per cent of changes in self-perceived performance is possible to be accounted for procedural justice; and 50.1 per cent to be accounted for interactional justice.

b) The coefficient of selected independent variables of the study are found to be positive to some extent, thus there is a direct relationship between practices by the management of the academic faculties of dimensions of organizational justice and self-perceived performance of staff.

c) The level of execution of distributive justice, procedural justice and interactional justice have had significant influence in reflecting on self-perceived performance of the faculty members. All the hypotheses constructed are supported in this study.

\section{Discussion and Conclusion}

According to Table 3, the R-Square indicate the degree to which the independent variable explains the variation in the dependent variable. The R-Square value (coefficient of determination) between Self-Perceived Performance (SPP) and three independent variables is $0.552,0.459$ and 0.501 which is less than one, respectively. The results indicate high correlations between the dependent and indipendent variables. The findings indicated above explain that all variables of orgaizational justice seem to deliver significant impact variation toward SPP among expatriate academicians which 
provided fair results between variables in this study.

This research has the intention to investigate the relationships between organizational justice and self-perceived performance in the context of Malaysia. The concept of organizational justice refers to the perceptions by the employees on the procedures, interactions and outcomes to be fair within their workplace. Justice functions as an intermediary which allowing organizational members to maintain respect and trust toward their organization even during unstable situations (Brockner and Wiesenfeld, 1996). Fairness is a crucial motivator of job performance in the organization. The more individuals are concerned about the organization, the more distressed they become when been treated unfairly.

\section{References}

Abdul, A.H.M. (2012). The Mediating Effects of Organisation Cultural Traits on The Relationship Between Transformational Leadership Style and Corporate Members' Attitudinal Outcomes: A Study of Government-Linked Companies in Malaysia. Doctoral thesis, Asia e University, School of Graduate Studies.

Al-Dmour, H. \& Awamleh, R.A. (2002). Effects of Transactional and Transformational Leadership Styles of Sales Managers on Job Satisfaction and Self-Perceived Performance of Sales People: A Study of Jordanian Manufacturing Public Shareholding Companies. Dirasat: Administrative Sciences Series, 29 (1), 247 - 261.

Alexander, S. \& Ruderman, M. (1987). The Role of Procedural and Distributive Justice in Organizational Behavior. In Chaudhry, N., Philip, P.J. \& Kumar, R. (2011). Impact of Organizational Justice on Organizational Effectiveness. Industrial Engineering Letter, 1 (3), 18-24.

Alsalem, M., \& Alhaiani, A. (2007). Relationship between Organizational Justice and Employees Performance. Aledari, $108,97-110$.

Al-Zu'bi, H.A. (2010). A Study of Relationship between Organizational Justice and Job Satisfaction. International Journal of Business Management, 5 (10), $102-109$.

Ambrose, M. L., \& Arnaud, A. (2005). Are Procedural Justice and Distributive Justice Conceptually Distinct? In Greenberg, J. \& Colquitt, J. (Eds.) The Handbook of Organizational Justice: Fundamental Questions About Fairness in the Workplace (pp. 59-84). Hillsdale, NJ: Erlbaum.

Ambrose, M. L., \& Schminke, M. (2003). Organization Structure as a Moderator of the Relationship Between Procedural Justice, Interactional Justice, Perceived Organizational Support and Supervisory Trust. Journal of Applied Psychology, 88, 295-305.

Baldwin, S. (2006). Organisational Justice. Retrieved January 2014 from Institute for Employment Studies: http://www.employmentstudies.co.uk

Ball, G., Trevino, L., \& Sims, H. (1994). Just and Unjust Punishment: Influences on Subordinate Performance and Citizenship. Academy of Management Journal, 37, 299-322.

Ball, K.T. (2006). LMX-Citizenship Behavior Relationship: Justice as a Mediator. Journal of Leadership \& Organization Development, 27 (2), 106-117.

Barley, S. R. \& Kunda, G. (1992). Design and Devotion: Surges of rational and normative ideologies of control in managerial discourse. In Cropanzo, R., Bowen, D.E. \& Gilliland, S.W. (2007). The Management of Organizational Justice. Academy of Management Perspectives, 21 (4), $34-48$.

Bies, R. J. (2001). Interactional (in) justice: The Sacred and The Profane. In Greenberg, J. \& Cropanzano, R. (Eds.), Advances in organizational justice, pp.89-118, Stanford, CA: Stanford University Press.

Brockner, J., \& Wiesenfeld, B. M. (1996). An Integrative Framework for Explaining Reactions to Decisions: Interactive Effects of Outcomes and Procedures. Psychological Bulletin, 120, 189-208.

Campbell J.P., McHenry, J.J. \& Wise, L.L. (1990). Modeling of Job Performance in a Population of Jobs. Personnel Psychology, 43, 313343.

Cohen-Charash, Y. \& Spector, P.E. (2001). The Role of Justice in Organizations: A Meta-Analysis. Organizational Behaviour and Human Decision Processes, 86, 278 - 321.

Colquitt, J.A., Conlon, D.E., Wesson, M.J., Porter, C.O., \& Ng, K.Y. (2001). Justice at The Millennium: A Meta-Analytic Review of 25 Years of Organizational Justice Research. Journal of Applied Psychology, 86, 425-445.

Colquitt, J. A., Greenberg, J., \& Zapata-Phelan, C. P. (2005). What is Organizational Justice? A Historical Overview. In J. Greenberg \& J. A. Colquitt (Eds.), The Handbook of Organizational Justice (pp. 3-56). Mahwah, NJ: Erlbaum.

Colquitt, J.A. \& Chertkoff, J.M. (2002). Explaining Injustice: The Interactive Effect of Explanation and Outcome Fairness Perceptions and Task Motivation. Journal of Management, 28 (5), 592-645.

Cropanzo, R., Bowen, D.E. \& Gilliland, S.W. (2007). The Management of Organizational Justice. Academy of Management Perspectives, $21(4), 34-48$.

Cropanzano, R., Prehar, C.A. \& Chen, P. Y. (2002). Using Social Exchange Theory to Distinguish Procedural from Interactional Justice. Group \& Organization Management, 27(3), 324-351.

Doðan, V. (2008). Ýlköðretim kurumlarýnda örgütsel adaletin örgütsel baðlýlýk üzerine etkisi [The Effect of Organisational Justice on Organisational Commitment in Primary Schools]. In Memduhoglu, H.B. \& Yildiz, A. I. (2014). Developing The Organizational Justice Scale and Examining Teachers' and School Administrators' Views About Organizational Justice in Primary Schools. MIER Journal of Educational Studies, Trends \& Practices, 4 (1), 33-50.

Elamin, A.M. \&Alomaim, N. (2011).Does Organizational Justice Influence Job Satisfaction and Self-Perceived Performance in Saudi 
Arabia Work Environment?.International Management Review, 7 (1), 38 - 49.

Erdogan, B., \& Liden, R.C. (2006). Collectivism as A Moderator of Responses to Organizational Justice: Implications for Leader-Member Exchange and Integration. Journal of Organizational Behaviour, 27, 1-17.

Field, A. (2005). Repeated-Measures Design, Discovering Statistics Using SPSS (pp. 427-482). London: SAGE Production.

Fernandes, C. \& Awamleh, R. (2006). Impact of Organizational Justice in An Expatriate Work Environment. Management Research News, 29 (11), $701-712$

Field, A. (2005). Discovering Statistics Using SPSS (2nd Ed.). London: Sage.

Goudarzvandchegini,M., Aghajannashtaei, R., \& Shabaninashtaee, M. (2012). Study of the Relationship between Organizational Justice and Organizational Commitment of Staff in Executive Organizations in Guilan Province, Iran. Journal of Basic and Applied Science Research, 2 (8), 8096-8100.

Hartman, S.J., Yrle, A.C. \& Galle, W.P.Jr. (1999). Procedural and Distributive Justice: Examining Equity in A University Setting. Journal of Business Ethics, 20 (4), $337-351$.

Jex, S.M. (2002). Organizational Psychology: A Scientist-Practitioner Approach. John Wiley \& Sons, New York.

Leung, K. \& Stephan, W.G. (2001). Social Justice from a Cultural Perspective. In Matsumoto, D. (Ed.), The Handbook of Culture and Psychology, 375 - 378. Oxford Press: New York.

Masterson, S. S, Lewis, K., Goldman, B. M, \& Taylor, M. S. 2000. Integrating Justice and Social Exchange: The Differing Effects of Fair Procedures and Treatment on Work Relationships. Academy of Management Journal, 43, $738-748$.

Nabatchi, T., Bingham, L.B. \& Good, D. (2007). Organizational Justice and Dispute Resolution: A Six-Factor Model for Workplace Mediation. International Journal of Conflict Management, 18, 148-176.

Nesbit, R., Nabatchi, T. \& Bingham, L.B. (2012). Employees, Supervisors, and Workplace Mediation: Experiences of Justice and Settlement. Review of Public Personnel Administration, XX (X), 1-28.

Nunnally, J.C. (1978). Psychometric Theory (2nd Ed.). New York: McGraw-Hill.

Pourezat, A. \& Ghoulipour, A. (2008). Studying the Structural Obstacles of Justice in Organization, Journal of Bardashte Dovom, 8, 5370.

Poole, W.L. (2007). Organizational Justice as a Framework for Understanding Union-Management Relations in Education. Canadian Journal of Education, 30 (3), $725-748$.

Robbins, S.P. (2001). Organizational Behaviour. New Delhi: Prentice Hall, Inc.

Robinson, K. (2004). The Impact of Individual Differences on the Relationship between Employee Perceptions of Organizational Justice and Organizational Outcome Variables. In Manouchehcri, M., Razavi, H.R. \& Emamgholizadeh, S. (2014). Correlation between Organization Justice and Employees' Performance in Golestan ProvinceBank Melli Iran. International Research Journal of Management Sciences, 2 (2), 29-35.

Viswesvaran, C. \& Ones, D.S. (2000). Perspectives on Models of Job Performance. International Journal of Selection and Assessment, $8(4), 216-226$.

Waldman D.A. (1994). The Contributions of Total Quality Management to A Theory of Work Performance. The Academy of Management Review, 19 (3), 510-36. 